Konservasi Hayati, 17 (2): 49-55, Oktober (2021)

https://ejournal.unib.ac.id/index.php/hayati/

p-ISSN: 0216-9487

email:konservasihayati@unib.ac.id

e-ISSN: 2722-1113

\title{
BIOLOGICAL ASPECTS AND CONSERVATION OF Rafflesia arnoldii : INDONESIAN ENDEMIC PLANT CONSERVATION
}

\author{
Angga Puja Asiandu ${ }^{*}$ \\ ${ }^{1}$ Master Student of Biology, Faculty of Biology, Universitas Gadjah Mada, Indonesia \\ * corresponding author : angga.puja.asiandu@mail.ugm.ac.id
}

\begin{abstract}
Rafflesia arnoldii is one of the rare endemic plants in Indonesia. This endemic plant has unique characteristics and has various kinds of modifications that differentiate it from other plants. However, this largest flower plant is classified as an endangered plant. It is due to its limited life cycle and distribution area. Many kinds of habitat destruction caused by human activities also threaten the existence of this endemic plant. Besides, it is highly dependent on the presence of its host plant, Tetrastigma spp. Therefore, conservation is needed. Conservation is implemented through in-situ and or ex-situ conservation. It can be optimized by utilizing ecotourism activities involving local communities.
\end{abstract}

Keywords: Conservation, Endemic Plant, Rafflesia arnoldii

\section{INTRODUCTION}

The biodiversity of both animals and plants in an area is the natural wealth source owned by the region. Each region has its unique plants and animals according to the vegetation characteristics of the region. Living things are found within various species with unique genetic variations according to their habitat. Meanwhile, the diversity of living things is known as biodiversity. Biodiversity comprises species diversity, genetic diversity, and habitat or ecosystem diversity (Kusmana \& Hikmat, 2015).

Indonesia is one of the mega biodiversity countries located on the equator. The location and climate of Indonesia are suitable for the life of various kinds of plants and animals. Also, the tropical climate in Indonesia supports many organisms to grow and reproduce well. These conditions are the reasons why Indonesia has a wide variety of endemic plants and animals. Endemic animals and plants are valuable biological sources in Indonesia (Atmansyah et al., 2017).

Indonesia has $25 \%$ of the total flowering plants globally, with species reaching up to
20,000 species. Based on the number of species, $40 \%$ of plant species found in Indonesia are endemic species or native to Indonesia. The most common plant family in Indonesia is Orchidaceae, which reaches 4,000 species. Woody plants include the Dipterocarpaceae family consisting of 386 species, Myrtaceae and Moraceae 500 species, and the Ericaceae family as many as 737 species (Kusmana \& Hikmat, 2015).

One of the Indonesian endemic plants is $R$. arnoldii. Rafflesia is a genus of the Rafflesiaceae family, which has the largest flower diameter in the world. It has a unique developmental system that is still a mystery and is interesting to study. The flower has a large cavity in the middle (Nikolov et al., 2013). The Rafflesiaceae family belongs to a holoparasitic endophytic family with certain modifications. This family has a reduced body and roots that are hard to identify (Nikolov et al., 2014).

$R$. arnoldii lives in several regions of Sumatra Island, especially in Bengkulu Province. $R$. arnoldii has an annual life cycle and has small populations in nature. 
Environmental problems and the length of the life cycle have caused this endemic Indonesian plant to be one of the endangered species, according to IUCN. This threat of extinction has led to the importance of the conservation effort of $R$. arnoldii (Ramadhani et al., 2017).

The threat of the preservation of Rafflesia is a challenge that must resolve immediately to avoid the extinction of that endemic flower due to the uniqueness of this endemic flower is a valuable natural resource of Indonesia. $R$. arnoldii protection efforts need to be implemented as early and optimally as possible. Optimization of the protection of $R$. arnoldii applies to various conservation strategies. Conservation is a science developed to protect certain species and ecosystems. Conservation activities require the participation of local communities (Wuisang, 2015).

In this article, the author discussed some biological aspects of $R$. arnoldii. Also, the author discussed some essential conservation strategies to support the preservation of this endemic species.

\section{METHODS}

This study is a descriptive research. Descriptive research is a study that seeks to describe a phenomenon. The purpose of descriptive research is to describe the phenomena that occur in nature (Nugrahani \& Hum, 2014; Alviana et al., 2019). The method used in this research is the library search or literature study. A literature study is a research method limited to collect data from various data sources without conducting research directly into the field or laboratory. This type of research is possible with certain limitations when field research cannot be carried out (Sari \& Asmendri, 2020). There are several stages in the library search method or literature review. They are designing the research, conducting the review process, conducting data analysis, and writing and describing data (Snyder, 2019).

\section{Data Analysis}

The data obtained and used in this study were secondary. Secondary data are data obtained from various references. Secondary data analysis is the process of analyzing data obtained from many sources. The stages in secondary data analysis are developing the research questions, data identification, and data evaluation (Jonhston, 2014).

\section{RESULT AND DISCUSSION Habitat of Rafflesia arnoldii}

$R$. arnoldii is a rare and unique species that grows in several regions in Indonesia, such as Bengkulu Province. This plant is used as the identity of the Bengkulu Province and is a natural resource of Indonesia (Muhaimin et al., 2016).

$R$. arnoldii is mostly found in the Bukit Barisan National Park, located in BengkuluLampung Province. The plant requires specific host plants, Tetrastigma spp. The hosts are lianas, including T. tuberculatum, T. curtisii, T. dunculare, T. scortechinii, T. diepenhorstii, T. papillosum, T. quadrangulum, T. bratum, $T$. harmandii, and T. loheri (Ramadhani et al., 2017). The life cycle of this endemic plant is highly dependent on its host plants (Mursidawati et al., 2015), as shown in Figure 1.

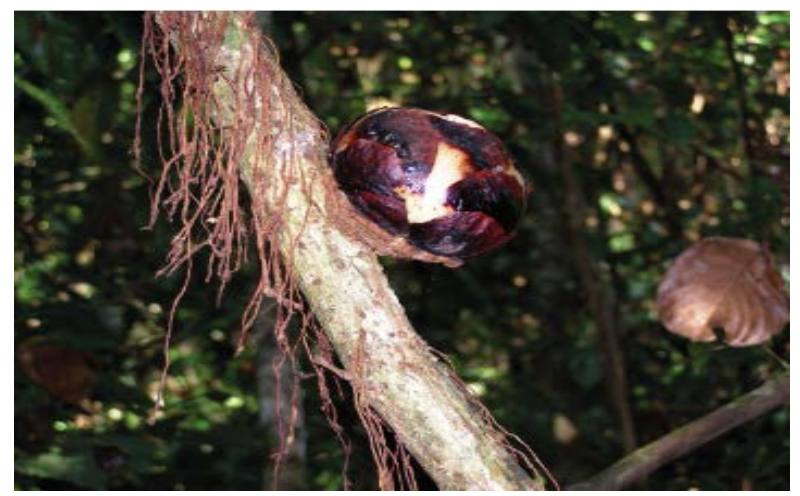

Figure 1. Rafflesia sp. Grows on the Root of Tetrastigma (Obtained from Mursidawati et al., 2015)

This endemic plant lives in an area within a temperature of $25-29{ }^{\circ} \mathrm{C}$. The humidity of its habitat is $95 \%$, and the soil $\mathrm{pH}$ is around 5.5. $R$. arnoldii lives in a habitat with an altitude ranging from 480 - 558 masl. Additionally, the location is about 7 meters from the nearest water source (Ramadhani et al., 2017). 


\section{Biological Aspects of $R$. arnoldii}

$R$. arnoldii is one of the members of the Rafflesiaceae family. This family is an endoparasitic group of plants. It grows inside the host plant tissue and utilizes the nutrients from that host. The only external part of Rafflesiaceae plants is their flowers. Meanwhile, $R$. arnoldii has the largest flower among other flowering plants in the world. Its flower has a diameter of up to $107 \mathrm{~cm}$ and a weight of up to $7 \mathrm{~kg}$ (Twyford, 2017). The morphology of its flower is shown in Figure 2.

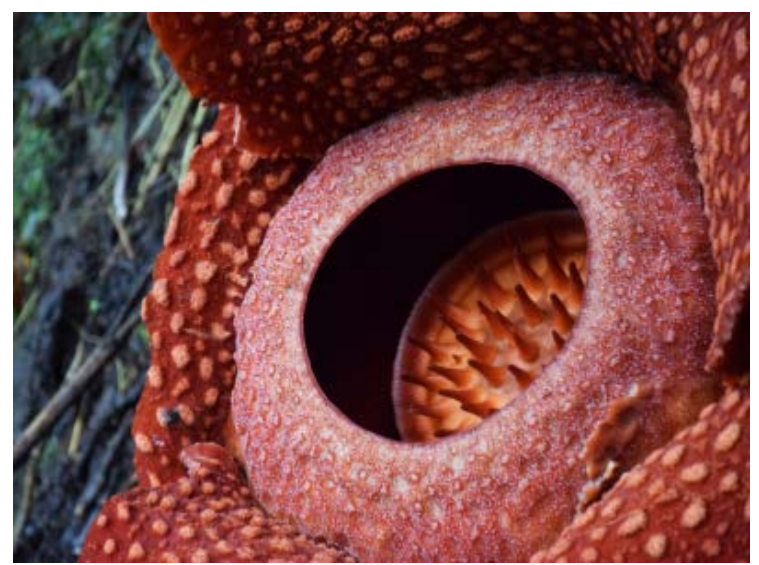

Figure 2. Morphology of $R$. arnoldii (Obtained from Wiatrowska, 2017)

$R$. arnoldii is an angiosperm plant that has undergone several modifications so that looking different from other angiosperm plants. The modifications that have occurred to this plant are still uncertain, the evolutionary concept of its flower formation is still confusing. It has a shaped-like bowls flower with a large cavity at the center. Biologists often refer to it as a blossom chamber (Nikolov et al., 2013).

Its flower is included as the unisexual and dioecious or two-house flowers. The flower pollination process is quite complicated. Male and female flowers must bloom simultaneously within the same period to carry out pollination assisted by flies and insects. Without this complex pollination process, the flower could not grow and develop. If the pollination process does not occur, this unique flower will continue to multiply in the host plant's tissue but cannot grow out of the host tissue. This limitation threatens genetic changes in the host plant and increases the rarity of this endemic plant in the future (Latiff, 2018).

$R$. arnoldii has a reddish-orange flower equipped with a cavity in the middle of the flower. The base and large cavity walls of the flower are formed from the perianth tube. The cover of the cavity is called the diaphragm. The cavity of its flower is surrounded by sterile organs known as the perianthial lobes, while the middle part or central column is the part that has fertile reproductive organs. The opening of the diaphragm serves as an entrance for insects that act as pollinators of the flower. The entry of insects, especially flies, is due to the pungent odor that comes from the cavity of its flower (Nikolov et al., 2013).

It has five perianthial lobes that are similar to sepals in angiosperms in general. Its flower has petals attached and is equipped with a diaphragm that covers the cavity in the center of the flower. Each perianth has a protective function and attracts insects to pollinate (Nikolov et al., 2014). The structure of the flower is shown in Figure 3.

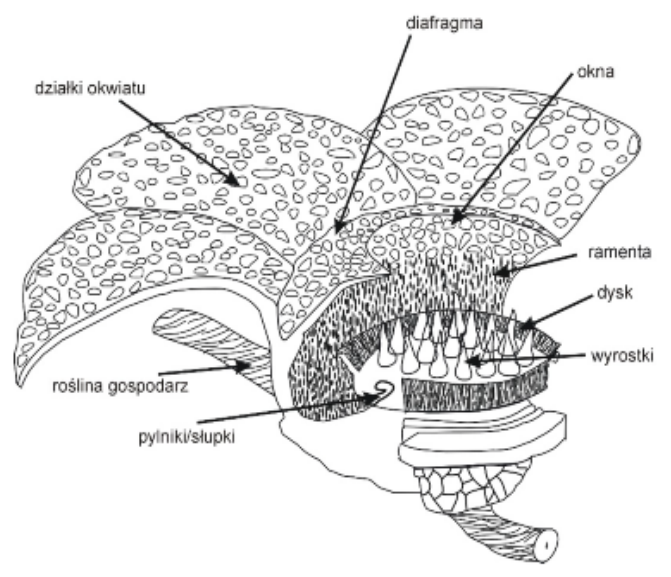

Figure 3. The Flower Structure of $R$. arnoldii (Obtained from Wiatrowska, 2017)

The blooming period of the flower ranges from 4 to 7 days. Several factors affect the length of its blooming period. Lack of available nutrients causes its flower unable to survive. Lack of water shortens the blooming period of the flower. Also, the blooming period can be disturbed by rodents that interfere with the flower's existence. The flower is prone to death within a diameter of 
less than $3 \mathrm{~cm}$ (Ramadhani et al., 2017). Its flower appears on the roots or stems of the host plant, Tetrastigma. Moreover, the Rafflesia flower does not have leaves and chlorophyll. Therefore, the flower cannot carry out photosynthesis, so it is included as a holoparasite (Mursidawati et al., 2015).

\section{Conservation of $\boldsymbol{R}$. arnoldii}

The narrow level of distribution in the wild is one of the threats to $R$. arnoldii. Also, environmental pressures such as deforestation, illegal logging, and uncontrolled activities decrease the ecosystem quality. If these problems do not overcome immediately, the extinction of this valuable endemic species will become real in the following few periods (Latiff, 2018).

Several threats to biodiversity are agricultural expansion, overexploitation, urbanization, industrialization, pollutions, wildfires, and global climate changes (Zegeye, 2017). Various environmental problems and the complex life cycle of the $R$ arnoldii cause this endemic Indonesian plant to be one of the endangered species, according to IUCN. These threats have led to the importance of the conservation effort of this endangered endemic species. The extinction of a species is an intolerable loss (Ramadhani et al., 2017).

Conservation of $R$. arnoldii needs to carry out due to biological, economic, scientific, and particular cultural-historical reasons and values. Based on Law No. 5 of 1990 regarding the conservation of natural resources, conservation is an effort made to manage living natural resources to utilize them wisely and ensure their sustainability and availability while maintaining and improving the quality of diversity and its values (Wuisang, 2015).

Conservation can be carried out to protect the ecosystem of many living things, including animals and plants. The activities aim to conserve and protect natural resources in an area. The strategies are implemented in various ways, such as through botanical exploration activities and the making of plant herbariums. Botanical exploration aims to determine the types of plants in specific locations to support the conservation effort and strategy (Tamin et al., 2017).

Conservation of biodiversity generally has three fundamental reasons. The first reason is the UN Charter, which states that all living things have the same right to live regardless of their value to humans. It means that every human should not disturb or threaten the life of other living things. Also, biodiversity has an essential role in the balance of life to support human survival. Another reason is that biodiversity is a natural resource with high economic values (Wuisang, 2015). Conservation of $R$. arnoldii is implemented with various conservation strategies. They include protecting its habitat, preserving its specimens, and optimally exploiting the potential that can be extracted from the plant while still paying attention to conservation aspects, such as ecotourism activities. The strategies should be implemented according to their respective goals and functions because conservation means protecting Indonesian biological resources and their application in many fields of life (Samedi, 2015; Wuisang, 2015).

\section{In-situ and Ex-situ Conservation of R. arnoldii}

In-situ conservation is the protection strategy of biological diversity within its natural habitat. In-situ conservation is one of the most effective conservation methods applied through single-use wildland, multipleuse wildland, and converting an area as managed for biological resources. The multiple-use wildland managements include national parks, natural monuments, protected landscapes, and other reserves (Zegeye, 2017).

In-situ conservation of $R$. arnoldii is carried out by determining its natural habitat as a National Park. Based on the Government Regulation of the Republic of Indonesia No. $108 / 2015$, the National Park is a natural conservation area that has an original ecosystem, managed by a zoning system used for research, science, education, cultural support, tourism, and recreation purposes. One of the National Parks that functions to 
preserve $R$. arnoldii is the Kerinci Seblat National Park that stretches across several regions of Bengkulu, Jambi, West Sumatra, and South Sumatera (Desmiwati \& Surati, 2017).

Meanwhile, ex-situ conservation is the strategy of protecting biological resources outside of their natural habitat. This strategy is implemented through the botanical garden, zoo, and collection of an organism's parts as sperm, seed, pollen, and tissue culture (Zegeye, 2017). The major ex-situ conservation strategies are nurseries, botanical gardens, zoos, breeding, sustainable reproduction centers, rescue and rehabilitation centers, germplasm banks, and aquariums (Mestanza-Ramón et al., 2020).

Ex-situ collections are essential in preserving $R$. arnoldii as an endemic species with a high threat of extinction. Ex-situ collections are used for habitat restoration and natural habitat restoration. The growth and development processes of species collected exsitu can be controlled to minimize extinction due to natural habitat destruction. Prioritized species in ex-situ collections are endangered species, economically potential, or have uniques socio-cultural values (Rahman, 2015). Moreover, the Ex-situ conservation of $R$. arnoldii is promising (Mandiriati et al., 2016) yet challenging. This endemic plant is highly dependent on its host. Therefore, conserving host plants is also needed to protect R.arnoldii and its habitat.

\section{Ecotourism-based conservation of Rafflesia arnoldii}

The other conservation strategy is ecotourism-based conservation. Rafflesia arnoldii has a unique morphological shape and color with a large flower diameter that attracts the community. This attraction is used as the support of its conservation effort by optimizing the ecotourism potential. Aesthetic values possessed by a species can attract people's attention, including refreshing, education, and research. This strategy is the funding source for facilities and infrastructures to support the conservation of this endemic plant (Atmansyah et al., 2017).
Additionally, the conservation of $R$. arnoldii can not be separated from the community's interference, especially those who live around its ecosystem. Community involvement in conservation needs to carry out with a preliminary approach in education and socialization. Outreach activities for the local community aim to provide understanding and knowledge about the importance of local biodiversity sustainability as Rafflesia arnoldii. Through education and socialization, it is expected that the community will be able to actively participate in preserving this endemic plant (Tamin et al., 2017).

\section{CONCLUSION}

$R$. arnoldii is one of the endemic plants in Indonesia. This endemic plant has a narrow habitat distribution, and its life cycle is highly dependent on the host plant. Also, many threats threaten this endemic plant. They cause $R$. arnoldii classified as one of the endangered species according to the IUCN. Therefore, the conservation effort is needed to persevere it. Conservation efforts include insitu and ex-situ protection of its life suppo rt systems, protection of ecosystems where $R$. arnoldii grows, preserving specimens, and optimizing ecotourism-based conservation.

The author suggests the optimization of ex-situ and in-situ conservation of Rafflesia arnoldii involving the local community. Also, efforts to protect the host plant must be implemented to support the preservation of this endemic plant.

\section{REFERENCES}

Alviana, E.D., Pujiana, T., Arianti, D., \& Yanfika, H. (2019). Communication in the Implementation of Jejar Legowo System in Murni Jaya, Tumijajar Subdistrict, Tulang Bawang Barat District. Mimbar Agribisnis. 5(2): 156164. doi: 10.25157/ma.v5i2.1906

Atmansyah., Yoza, D., \& Arlita, T. (2017). The Identification of Ecotourism Potential in Pulau Jemur Conservation Area Pasir Limau Kapas District Rokan 
Hilir Regency. Jurnal JOM FAPERTA. 4(1):1-11.

Desmiwati, Surati. (2017.) Efforts to Resolve the Problem of Forest Area Conservation on the National Park in the Island of Sumatera. Jurnal Penelitian Kehutanan Wallacea. 6(2): 135-146.

doi:10.18330/jwallacea.2017.vol6iss2p p135-146

Jonhston, M.P. (2014). Secondary Data Analysis: A Method of Which the Time Has Come. Qualitative and Quantitative Methods in Libraries. 3: 619-626.

Kusmana, C.A., \& Hikmat, A. (2015). The Biodiversity of Flora in Indonesia. Jurnal Pengelolaan Sumberdaya Alam dan Lingkungan. 5(2): 187-198. doi: 10.19081/jpsl.5.2.187

Latiff, A. (2018). Viability of Having the Gigantic Rafflesia Flowers in Our Park. Open Acces Journal of Science. 2(2):106-107. doi:10.15406/oajs.2018.02.00053

Mandiriati, H., Marsono, D., Poedjirahajoe, E., \& Sadono. R. (2016). Conservation of Javanese Plant Species Diversity in Kebun Raya Baturaden in the Former Limited Production Forest Area. [Konservasi Keanekaragaman Jenis Tumbuhan Jawa di Kebun Raya Baturaden di Kawasan Bekas Hutan Produksi Terbatas]. Jurnal Ilmu Lingkungan. 14(1): 33-38. Doi: https://doi.org/10.14710/jil.14.1.33-38

Mestanza-Ramón, C., Henkanaththegedara, S.M., Duchicela, P., Tierras, Y.V., Capa, M.S., Mejía, D.C., Gutierrez, M.J., Guamán, M.C., \& Ramón, P.M. (2020). In-situ and Ex-situ Biodiversity Conservation in Ecuador: A review of policies, actions and challenges. Diversity. $\quad 12(8)$ : $\quad 315$ https://doi.org/10.3390/D12080315 https://www.mdpi.com/14242818/12/8/315
Muhaimin, M., Hidayat, I.W., \& Muslim. (2016). Plants Exploration and Vegetation Compotition Study in Hill Zone of Mouth Patah, Bengkulu. Jurnal Prosiding Seminar Nasional Masyarakat Biodiversitas Indonesia. 2(2):132-137. doi:10.13057/psnmbi/m020202

Mursidawati, S., Ngatari, Irawati, Cardinal, S., and Kusumawati, R. (2015). Ex Situ Conservation of Rafflesia patma Blume (Rafflesiaceae) - an Endangered Emblematic Parasitic Species from Indonesia. The Journal of Botanic Garden Horticulture. 13: 99-110. doi: https://doi.org/10.24823/Sibbaldia.201 5.77

Nikolov, L.A., Endress, P.K., Sugumaran, M., Sasirat, S., Vessabutr, S., Kramer, E.M., \& Davis, C.C. (2013). Developmental Origins of the World's Largest Flowers, Rafflesiaceae. PNAS. 110(46): 18578-18583. Doi: 10.1073/pnas.1310356110

Nikolov, L.A., Staedler, Y.M., Manickam, S., Schonenberger, J., Endress, P.K., Kramer, E.M., \& Davis, C.C. (2014). Floral Structure and Development in Rafflesiaceae with Emphasis on Their Exceptional Gynoecia. American Journal of Botany. 10(2): 225-243. doi:10.3732/ajb.1400009

Nugrahani, F., \& Hum, M. (2014). Metode Penelitian Kualitatif. Solo: Cakra Books.

Rahman, W. (2015). Criteria for Determining the Priority Species of Threathened Rhododendron spp. For Ex Situ Conservation in Indonesia. Jurnal Buletin Kebun Raya. 18(1): 31-40. Doi:10.14203/bkr.v18i1.155

Ramadhani, D.N., Setiawan, A., \& Master, J. (2017). Population and Environmental Condition of Raflessia arnoldii in Rhino Camp Sukaraja Atas Resort Bukit Barisan Selatan National Park (BBSNP). Jurnal Sylva Lestari. 5(2): 128-141.

doi: 
http://dx.doi.org/10.23960/jsl25128141

Samedi. (2015). Biodiversity Conservation in Indonesia: Recommendations for Improving Conservation Laws. [Konservasi Keanekaragaman Hayati di Indonesia: Rekomendasi Perbaikan Undang-undang Konservasi]. Jurnal Hukum Lingkungan. 2(2): 10-28. doi: 10.38011/jhli.v2i2.23

Sari, M., \& Asmendri. (2020). Library Research in Science Education Research. [Penelitian Kepustakaan (Library Research) dalam Penelitian Pendidikan IPA]. Natural Science: Jurnal Penelitian Bidang IPA dan Pendidikan IPA. 6(1): 41-53. doi: 10.15548/nsc.v6i1.1555

Snyder, H. (2019). Literature Review as a Research Methodology: An Overview and Guidelines. Journal of Business Research. 104: 333-339. doi: 10.1016/j.jbusres.2019.07.039

Tamin, R.P., Anggraini, R., \& Ulfa, M. (2017). Counceling and Training of Forest Botanical Exploration as Forest Conservation Effort. [Penyuluhan dan Pelatihan Eksplorasi Botani Hutan dalam Upaya Konservasi Hutan]. Jurnal Karya Abdi Masyarakat. 1(2): 119-128.

Doi: https://doi.org/10.22437/jkam.v1i2.429 0

Twyford, A.D. (2017). New Insight into the Population Biology of Endoparasitic Rafflesiaceae. American Journal of Botany. 104(10): 1433-1436. doi: 10.3732/ajb.1700317.

Wiatrowska, B. (2017). Raflessia arnoldii - a Plant with the Largest Flowers in the World. [Bukietnica Arnolda (Rafflesia arnoldii)-Roslina o Najwiekszych Kwiatach Swiata]. Nauka Przyroda Technologie. 11(4): 365-373. http://dx.doi.org/10.17306/J.NPT.0021 5
Wuisang, C. (2015). Conservation of Biodiversity in Urban Areas: Evaluation of a Green Corridor Landscape in Manado City. [Konservasi Biodiversitas di Wilayah Perkotaan: Evaluasi Lansekap Koridor Hijau di Kota Manado]. Jurnal Media Matrasain. 12(2): 47-60.

Zegeye, H. (2017). In situ and ex situ conservation: Complementary approaches for maintaining biodiversity. Ijres, 4: 1-12. 